\title{
MUSCULAR ANATOMY OF THE PECTORAL AND FORELIMB OF Caiman crocodilus crocodilus (LINNAEUS, 1758) (CROCODYLIA: ALLIGATORIDAE)
}

\author{
ANATOMIA MUSCULAR DO MEMBRO TORÁCICO DE Caiman crocodilus \\ crocodilus (LINNAEUS, 1758) (CROCODYLIA: ALLIGATORIDAE)
}

\author{
Fabiano Campos Lima ${ }^{1}$ \\ Anastácia Vale Leite ${ }^{1}$ \\ André Luiz Quagliatto Santos ${ }^{2}$ \\ Dayane Kelly Sabec-Pereira ${ }^{1}$ \\ Eugênio Gonçalves Araújo ${ }^{3}$ \\ Kleber Fernando Pereira ${ }^{1^{*}}$
}

${ }^{1}$ Universidade Federal de Goiás, Regional de Jataí, Ciências Biológicas, Jataí, GO, BR 2Universidade Federal de Uberlândia, Faculdade de Medicina Veterinária, Uberlândia, MG 3Universidade Federal de Goiás, Escola de Veterinária e Zootecnia, Goiânia, GO, Brasil *Autor para correspondência - kpereiraufg@gmail.com

\begin{abstract}
Among the Brazilian crocodilian, Caiman crocodilus crocodilus is widely distributed, given its adaptation to diverse habitats and their generalist diet. Information about the reproductive and ethological character of this species is abundant, whereas morphological data are still scarce. This study aimed to identify and report the muscles and their origin and the insertion into the pectoral and forelimb of $C$. crocodilus crocodilus. We used two male specimens, adults, belonging to the collection of the UFG - Jataí. We performed usual procedures for dissection and further individualization, withdrawal of members, and observation of muscle origins and insertions. The musculature of $C$. crocodilus crocodilus generally conservative is similar to C. latirostris and A. mississippiensis. The muscles of the pectoral girdle showed little variation among crocodilians. In the forelimb, the triceps muscle has five distinct heads and biceps has only one. The extensor and flexor surface of the hand showed similar topography to A. mississippiensis. We described some differences in the origin and insertion of certain muscles, as well as the classification and topography of some flexor and extensor muscles in the forearm segment. The distal segments showed more variations, which probably reflects the variety of locomotor habits among crocodilians.
\end{abstract}

Keywords: Common caiman; crocodilians; myology; muscle; reptiles.

\section{Resumo}

Dentre os crocodilianos brasileiros, Caiman crocodilus crocodilus apresenta ampla distribuição, haja vista sua adaptação a habitats diversificados e sua dieta generalista. Informações de caráter etológico e reprodutivo acerca desta espécie são abundantes, enquanto dados morfológicos são ainda escassos. Objetivou-se identificar e relatar os músculos e suas origens e inserções nos segmentos da cintura e membro torácico de $C$. crocodilus crocodilus. No estudo, foram utilizados dois exemplares machos, adultos, pertencentes ao acervo da UFG - Jataí. Para isto utilizaram-se métodos usuais em dissecação e posteriormente os músculos foram individualizados, descritos e sua origem e inserção determinadas. A musculatura de $C$. crocodilus crocodilus é conservativa, sendo similar a C. latirostris e A. mississippiensis. Os músculos da cintura peitoral apresentaram uma pequena variação dentre os 
crocodilianos avaliados. No membro torácico, o tríceps possui cinco ventres distintos e o bíceps apenas um. O grupo de flexores e extensores da região do ante-braço apresenta topografia similar aquela descrita para A. mississippiensis. Algumas diferenças na origem, inserção, classificação e topografia de alguns músculos flexores e extensores foram descritas. O segmento distal do membro apresentou mais variação, o que provavelmente reflete diferenças no padrão locomotor entre os crocodilianos.

Palavras-chave: Crocodiliano; jacaretinga; miologia,; músculo, répteis.

Enviado em: 28 janeiro 2015

Aceito em 26 fevereiro de 2016

\section{Introduction}

Among vertebrates, reptiles were the first animals to adapt to the life in dry environments. Among reptiles, crocodilians differed as a group approximately 200 million years ago, in the Triassic, and belong to the subclass Archosauria. The Archosauria from Crocodylia is included in the living crocodilians. Anatomically, they have elongated skull, terminal nostril, secondary palate, thecodont teeth, with webbed fingers, and an excluded pubis from the acetabulum. ${ }^{(1,2)}$

The Alligatoridae family includes alligators and caimans. ${ }^{(3-6)}$ These reptiles have a relatively broad snout and an unclearly demarcated skull, small or secondarily closed supratemporal opening, strong teeth, and mandibular teeth fitting into the internal cavity of the mouth. They live in flooded regions throughout the American continent and China, ${ }^{(7,8)}$ consisting of Alligator mississippiensis, Alligator sinensis, Caiman crocodilus crocodilus, Caiam latirostris, Caiman yacare, Melanosuchus niger, Paleosuchus palpebrosus, and Paleosuchus trigonatus.

Popularly known in Brazil as black alligator, glasses caiman, and jacaretinga, C. crocodilus crocodilus (Linnaeus, 1758) inhabits floodplains in the Midwest, Southeast and Northern in basins of the Amazon, Orinoco, Araguaia, and Tocantins rivers. ${ }^{(9-11)}$ It presents a broad distribution concerning other species of Brazilian crocodilians, and in some places, the introduction of this species happened by the scape from zoos and breeding farms. Recently it was reported at the border between Ceará and Piauí States. (12)

C. crocodilus crocodilus have a diversified diet, feeding on snails, fish, amphibians, birds, and small mammals. They can reach 2.5 meters in total length, and they have the lightest color of all species occurring in Brazil. When compared to M. niger, C. crocodilus crocodilus is a generalist animal that may use environments modified by humans, such as canals and dams, and present a more varied diet. This species builds nests in an igloo format, using material from the litter, or that could be the basis of a semi-shrub formation, shrubs and trees, from environments of forests, savannas, and fields. ${ }^{(10,11,13)}$ Tetrapoda quadrupeds have a diversified postural capacity during the locomotion. ${ }^{(6)}$ Crocodilians have different locomotion patterns. They can drag on the ground, move slightly upright, or swim. ${ }^{(5,14)}$ The anatomy of modern representatives of this group presents similar characteristics among locomotor species, ${ }^{(15)}$ and an equivalent morphology and function could lead to the conclusion that members, for example, have a high degree of conservatism. The maintenance of these features should be similar to the occupation of ecological niches along the evolutionary history of this group. ${ }^{(16)}$

Hutchinson and Gatesy, ${ }^{(17)}$ based on the functional anatomy, reconstructed the phylogeny of the Archosauria group of locomotion and inferred the evolution was gradual, involving a plesiomorphic postural mechanism. Hutchinson ${ }^{(18)}$ reported these changes altered the anatomy and motor control, although in some cases the member function evolved without modifications in motor control.

The evolution of reptiles was a milestone for the adaptation to terrestrial life and occupation. It contributed to other living creatures that came from other reptiles; therefore, the aim of this paper is to describe the muscular anatomy of the forelimb of $C$. crocodilus crocodilus, offering subsidies for interpreting the anatomy and physiology of the locomotion muscle of this group. 


\section{Materials and Methods}

For this study, we used two young adult, male $C$. crocodilus crocodilus, measuring approximately $1.5 \mathrm{~m}$ in length, belonging to the collection of the Human and Comparative Anatomy Laboratory of the Federal University of Goiás - Jataí.

We started the usual dissection procedures with a longitudinal incision along the midline, and later we refuted the skin in the region. The specimens were fixed in formalin $10 \%$ and kept in $70 \%$ alcohol solution. Following muscle individualization of regions of interest, we identified the muscles, removed the members for a better observation of the origins, and performed muscle insertions. All the material was photographed with a digital camera (Camera Sony a200, 10.2mpx).

We collected the animals in November 2007, in Araguaia river, Goiás, Brazil, under the permit number 13159-1/2007 SISBIO. We kept the animals in the lab for other experiments. They came to death, and we used their bodies in this investigation under license of the Research Committee of Ethics in Animal Experimentation of Federal University of Uberlandia (CEUA 032/09).

\section{Results and Discussion}

A description of the anatomy, topography, origin and insertion of the pectoral girdle and forelimb muscles of C. crocodilus crocodilus follows in Tables 1, 2, and 3, and in Figures 1, 2, and 3.

The pectoralis muscle is usually large and runs the sternal margin or adjacent structures, such as the humerus or scapula ${ }^{(19-21)}$ (Fig 1). According to Romer, ${ }^{(19)}$ for reptiles to present a pleisiomorphic condition, they have to have a single chest, as in lepdosauria and testudines ${ }^{(22)}$. Crocodilians, however, presents segmentation on superficial and deep head. ${ }^{(20)}$ Romão et al. ${ }^{(23)}$ reported the existence of a cranial parallel fiber segment and other caudal oblique fiber segment. This was also reported with three heads, ${ }^{(22,24)}$ an inconstant deep head, superimposed by the flow head that may occur. Birds have two divisions, ${ }^{(25)}$ with some consideration by Hudson et al., ${ }^{(26)}$ the existence of a third head. $C$. crocodilus crocodilus division between segments (head) of the chest was not conspicuous but the extensive source along the sternal border and the direction of the fibers suggests the division.

In all described crocodilians, the segments converged into one tendon that inserted into the deltopectoral crest of the humerus. ${ }^{(19,22-24)}$ Meers $^{(24)}$ pointed out, in the Crocodilus actus, the pectoralis had a unique origin fixed in the third gastralia. According to Diogo et al., ${ }^{(21)}$ the different segmentations of the pectoralis between reptiles and Archosauria indicated that this configuration was acquired independently in evolution. According to Romão et al., ${ }^{(23)}$ the pectoralis in C. latirostris showed greater longitudinal distance from A. mississippiensis, C. siamensis, C. actus, O. tetraspis, and $G$. gangeticus, ${ }^{(24)}$ offering better possibility of mobility.

The supracoraoideus complex consists of three muscles in A. mississippiensis, C. siamensis, C.actus, O. tetraspis, G. gangeticus, ${ }^{(24)}$ and $C$. latirostris. ${ }^{(23)}$ For $C$. crocodilus crocodilus, the intermediate head is not defined as showed in reports for other crocodilians. Meers ${ }^{(24)}$ described a common tendon of insertion for intermediate and short heads, which can be difficult to distinguish in the bellies of C. crocodilus crocodilus. An alleged mechanical advantage was observed among $C$. latirostris, $A$. mississippiensis, C. siamensis, C. actus, O. tetraspis, and G. gangeticus ${ }^{(24)}$ for the supracoraoideus complex, originating in the lateral humerus in proximal aspect. ${ }^{(23)}$

Deep to the pectoralis muscle there was a pair of costocoracoideus (superficialis and profundus) it assisted in retraction of the coracoid, although there was no significant action to provide stability to this segment. In A. mississippiensis, C. siamensis, C. actus, O. tetraspis, G. gangeticus, ${ }^{(24)}$ and C. crocodilus crocodilus, its origin occurs in the costal margin and insertion into the caudal border of the coracoid (superficialis) and craniolateral margin of sternal plate and ventral surface of the coracoid (profundus) (Fig 1). Romão et al., ${ }^{(23)}$ however, described the costocoracoideus superficialis and profundus both originating in the deep sternal border of $C$. latirostris. 
Table 1: Dorsal and ventral muscles of the pectoral girdle of $C$. crocodilus crocodilus

\begin{tabular}{|c|c|}
\hline Muscle & Insertion \\
\hline Trapezius & $\begin{array}{l}\text { Thoracodorsal fascia, } \\
\text { spinous process along Cranial margin of the Broad and thin, occupying the } \\
\text { the midline in cervical scapula } \\
\text { and thoracic segment }\end{array}$ \\
\hline Latissimus dorai & $\begin{array}{l}\text { Through a common } \\
\text { Thendon with the teres Superficial, overlaying by } \\
\text { Thoracodorsal fascia, } \\
\text { caudally by trapezius in craniodorsal serratus ventralis thoracis. Flat, } \\
\text { surface, distal to the criangular and parallel fibers, } \\
\text { head of the humerus continuous with trapezius }\end{array}$ \\
\hline Levator scapulae & $\begin{array}{l}\text { Craniodorsal margin of Elongated with fibers } \\
\text { the scapula } \\
\text { trantudinally arranged, deep by }\end{array}$ \\
\hline Deltoideus scapularis & $\begin{array}{l}\text { Craniodistal margin of Proximal humerus, } \\
\text { distal of deltopectoral } \\
\text { the scapula } \\
\text { crest }\end{array}$ \\
\hline Deltoideus clavicularis & $\begin{array}{l}\text { Proximal surface of the } \\
\text { cranial margin of Medial tubercule of the } \begin{array}{l}\text { Broad and triangular. Occupies } \\
\text { large area on the surface of the } \\
\text { scapula }\end{array}\end{array}$ \\
\hline Teres major & $\begin{array}{l}\text { Distal caudal surface of Proximal humerus } \\
\text { the scapula }\end{array}$ \\
\hline Supracoracoideus longus & $\begin{array}{l}\text { Ventral surface of the Medial tubercule of the Robust, thick and superficial to } \\
\text { coracoid }\end{array}$ \\
\hline Supracoracoideus brevis & $\begin{array}{l}\text { Lateral surface of the Deltopectoral crest } \\
\text { acromion }\end{array}$ \\
\hline Pectoralis & $\begin{array}{l}\text { Broadly along the Apex of the Extensive, thick, flat and } \\
\text { lateral margin of the Apex triangular. Superficial on the } \\
\text { sternum, on midline deltopectoral crest } \\
\text { ventral aspect }\end{array}$ \\
\hline $\begin{array}{l}\text { Costocoracoideus } \\
\text { superficialis }\end{array}$ & $\begin{array}{l}\text { Cranial margin of the Caudal margin of the Broad belly. The insertion also } \\
\text { first sternal rib can occur on the sternum }\end{array}$ \\
\hline $\begin{array}{c}\text { Costocoracoideus } \\
\text { profundus }\end{array}$ & $\begin{array}{l}\text { Caudal margin of Cranial edge of the Overlapped by costocoracoid } \\
\text { stemal ribs } \\
\text { coracoid surface of the superficialis. It is small and } \\
\text { shows oblique fibers }\end{array}$ \\
\hline Supracoracoideus longus & $\begin{array}{l}\text { Ventral surface of the Medial tubercule of the Robust, thick fan-shaped and } \\
\text { coracoid } \\
\text { humerus }\end{array}$ \\
\hline Supracoracoideus brevis & $\begin{array}{l}\text { Lateral surface of the Deltopectoral crest } \\
\text { acromion }\end{array}$ \\
\hline Subscapularis & $\begin{array}{l}\text { Medial surface of the Proximal humerus, into } \\
\text { the glenohumeralis joint }{ }_{\text {mead, thick e long. Occupies the }} \\
\text { capsule }\end{array}$ \\
\hline Scapulohumeralis & $\begin{array}{l}\text { Lower portion of the } \\
\text { dorsal surface of the Proximal humerus } \\
\text { scapula near the } \\
\text { glenoid edge }\end{array}$ \\
\hline
\end{tabular}


Table 2: Forelimb muscles of the proximal segment of $C$. crocodilus crocodilus

\begin{tabular}{|c|c|c|c|}
\hline Muscle & Origin & Insertion & Features \\
\hline $\begin{array}{l}\text { Coracobrachialis brevis } \\
\text { ventralis }\end{array}$ & $\begin{array}{l}\text { Ventral surface of the } \\
\text { coracoid }\end{array}$ & $\begin{array}{l}\text { Proximal humerus in } \\
\text { caudoventral surface }\end{array}$ & $\begin{array}{l}\text { Broad, fan-shaped and } \\
\text { extensive. Deep to pectoralis }\end{array}$ \\
\hline Biceps brachii & $\begin{array}{l}\text { Cranial edge of the } \\
\text { coracoid }\end{array}$ & $\begin{array}{l}\text { Caudal surface of } \\
\text { proximal radius (short } \\
\text { tendon on the radial } \\
\text { tuberosity) }\end{array}$ & $\begin{array}{l}\text { Thick, large, prominent and } \\
\text { fusiform parallel-fibered } \\
\text { muscle. The tendon of origin } \\
\text { overlaid the pectoralis. }\end{array}$ \\
\hline Braquialis & $\begin{array}{l}\text { Proximal humerus } \\
\text { dyaphisis, distal to } \\
\text { the deltopectoral crest }\end{array}$ & $\begin{array}{l}\text { Caudal surface of } \\
\text { proximal radius }\end{array}$ & $\begin{array}{l}\text { Broad muscle that occupies the } \\
\text { craniomedial aspect of humerus } \\
\text { and inserts with conjunction the } \\
\text { biceps }\end{array}$ \\
\hline Triceps longus lateralis & $\begin{array}{l}\text { Dorsal glenoid edge } \\
\text { of the scapula }\end{array}$ & $\begin{array}{l}\text { Proximal ulna, lateral } \\
\text { aspect of the olecranon }\end{array}$ & $\begin{array}{l}\text { Superficial, longitudinal } \\
\text { parallel fibers and with a } \\
\text { largely origin tendon }\end{array}$ \\
\hline Triceps longus caudalis & $\begin{array}{l}\text { Surface of the scapula } \\
\text { and coracoid via a } \\
\text { tendinous arc } \\
\text { attached to these } \\
\text { bones }\end{array}$ & $\begin{array}{l}\text { Proximal ulna, } \\
\text { olecranon process }\end{array}$ & $\begin{array}{l}\text { Long, broad, pinnate and } \\
\text { superficial, caudal located to } \\
\text { the longus lateralis belly }\end{array}$ \\
\hline Triceps brevis cranialis & Proximal humerus & $\begin{array}{l}\text { Proximal ulna, } \\
\text { olecranon process }\end{array}$ & $\begin{array}{l}\text { Short and overlapped by longus } \\
\text { lateralis and lies dorsal to the } \\
\text { humeroradialis }\end{array}$ \\
\hline $\begin{array}{l}\text { Triceps brevis } \\
\text { intermedius }\end{array}$ & $\begin{array}{l}\text { Dorsal surface of the } \\
\text { proximal humerus }\end{array}$ & $\begin{array}{l}\text { Proximal ulna, } \\
\text { olecranon process }\end{array}$ & $\begin{array}{l}\text { Occupies the largest area of the } \\
\text { deep surface of the humerus. } \\
\text { overlapped by longus lateralis } \\
\text { and humeroradialis }\end{array}$ \\
\hline Triceps brevis caudalis & $\begin{array}{l}\text { caudal humerus in the } \\
\text { medial surface }\end{array}$ & $\begin{array}{l}\text { Proximal ulna, } \\
\text { olecranon process }\end{array}$ & $\begin{array}{l}\text { Long and narrow with } \\
\text { longitudinal fibers deep to } \\
\text { longus lateralis belly }\end{array}$ \\
\hline Humeroradialis & $\begin{array}{l}\text { Proximal humerus, } \\
\text { distal to the } \\
\text { deltopectoral crest }\end{array}$ & $\begin{array}{l}\text { Proximal radius, } \\
\text { humeroradialis crest }\end{array}$ & $\begin{array}{l}\text { Robust, long, thick and } \\
\text { superficial in the cranial surface } \\
\text { of the humerus. }\end{array}$ \\
\hline
\end{tabular}
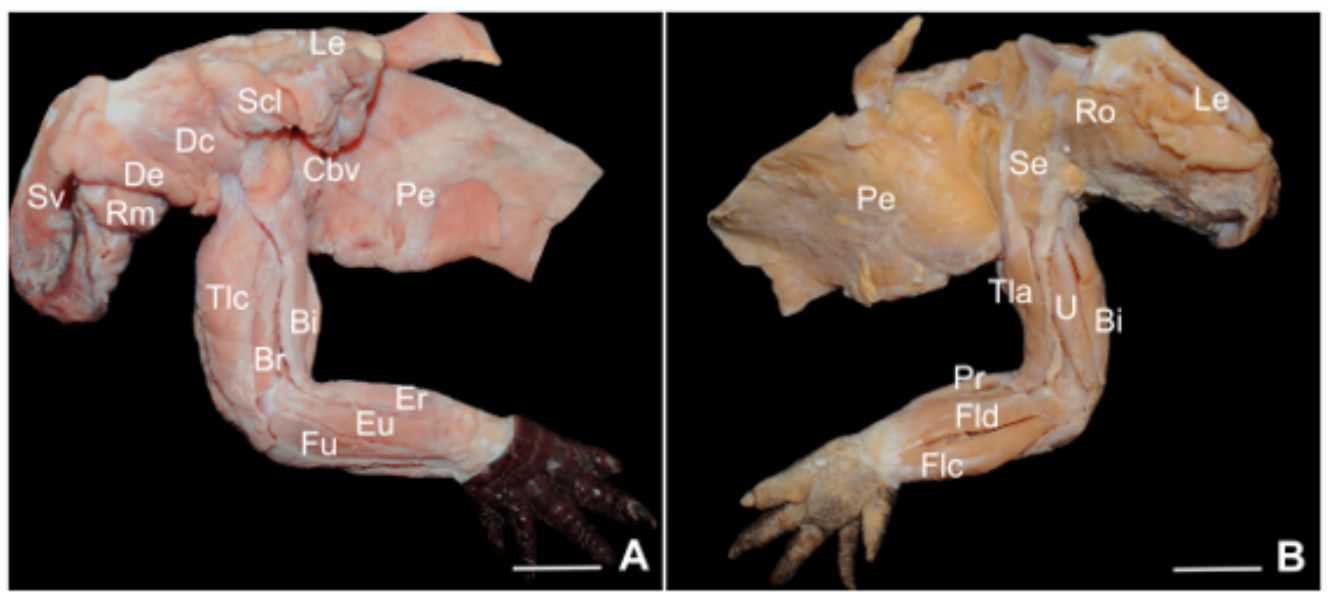

Figure 1: Pectoral and Forelimb of the Caiman crocodilus crocodilus, lateral view (A). $\mathrm{Pe}$, pectoralis; $\mathrm{Scl}$, supracoracoidus longus; De, deltoideus scapularis; Dc, deltoideus clavicularis; Le, levator scapulae; $\mathrm{Cbv}$, coracobrachialis brevis ventralis; $\mathrm{Rm}$, teres major; $\mathrm{Sv}$, serratus ventralis; $\mathrm{Br}$, brachialis; $\mathrm{Bi}$, biceps brachii; $\mathrm{Tlc}$, triceps longus caudalis; Eu, extensor carpi ulnaris; Er, extensor carpi radialis; Fu, flexor ulnaris. Medial view (B). Se, subscapularis; Ro, rhomboideus; Tla, triceps longus lateralis; U, Humeroradialis; $\mathrm{Pr}$, pronator teres; Fld, flexor digitorum longus; Flc, flexor carpi ulnaris. ScaleBar $=1 \mathrm{~cm}$. 
Table 3: Forelimb muscles of the distal segment of C. crocodilus crocodilus

\begin{tabular}{|c|c|c|c|}
\hline Muscle & Origin & Insertion & Features \\
\hline Supinator & $\begin{array}{l}\text { Cranial epicondyle of } \\
\text { the humerus }\end{array}$ & $\begin{array}{l}\text { Distal radius, cranial } \\
\text { surface }\end{array}$ & $\begin{array}{l}\text { Large and superficial. Lateral to } \\
\text { the extensor carpi radialis } \\
\text { longus }\end{array}$ \\
\hline $\begin{array}{l}\text { Extensor carpi radialis } \\
\text { brevis }\end{array}$ & $\begin{array}{l}\text { Pars radialis: distal } \\
\text { half of the radius } \\
\text { Pars ulnaris: medial } \\
\text { edge of the ulna }\end{array}$ & $\begin{array}{l}\text { Proximal surface of the } \\
\text { radiale }\end{array}$ & $\begin{array}{l}\text { The pars radialis is small and } \\
\text { deep to supinator. The pars } \\
\text { ulnaris is large and occupies the } \\
\text { deep rezion }\end{array}$ \\
\hline Extensor carpi ulnaris & $\begin{array}{l}\text { Cranial epicondyle of } \\
\text { the humerus }\end{array}$ & Metacarpal II & $\begin{array}{l}\text { Long and broad, superficially } \\
\text { located in the cranial aspect }\end{array}$ \\
\hline Flexor ulnaris & $\begin{array}{l}\text { Cranial epicondyle of } \\
\text { the humerus }\end{array}$ & Distal ulna & $\begin{array}{l}\text { Broad, fusiform, superficial and } \\
\text { lateral of the antebrachium }\end{array}$ \\
\hline Abductor radialis & $\begin{array}{l}\text { Cranial epicondyle of } \\
\text { the humerus }\end{array}$ & $\begin{array}{l}\text { Proximal half of the } \\
\text { radius }\end{array}$ & $\begin{array}{l}\text { Small and deep to supinator and } \\
\text { extensor carpi radialis longus }\end{array}$ \\
\hline $\begin{array}{c}\text { Extensor carpi radialis } \\
\text { longus }\end{array}$ & $\begin{array}{l}\text { Cranial epicondyle of } \\
\text { the humerus }\end{array}$ & Radiale & $\begin{array}{l}\text { Long, fusiform and parallel } \\
\text { fibers }\end{array}$ \\
\hline Pronator teres & $\begin{array}{l}\text { Caudal epicondyle of } \\
\text { the humerus }\end{array}$ & $\begin{array}{l}\text { Distal half of the } \\
\text { radius }\end{array}$ & Large, thick and longitudinal \\
\hline Flexor digitorum longus & $\begin{array}{l}\text { Pars humeri: caudal } \\
\text { epicondyle of the } \\
\text { humerus } \\
\text { Pars ulnaris: caudal } \\
\text { surfasse of the ulna. } \\
\text { Pars carpalis: distal } \\
\text { carpals }\end{array}$ & $\begin{array}{l}\text { Broad tendon related } \\
\text { to the Pisiform and the } \\
\text { palmar aponeurosis. } \\
\text { Attached in distal } \\
\text { phalangx of the digits } \\
\text { I, II and III }\end{array}$ & $\begin{array}{l}\text { Three belly complex muscle. } \\
\text { Long and parallel-fibered with } \\
\text { a common tendon on the palmar } \\
\text { region that branches and inserts } \\
\text { on digits }\end{array}$ \\
\hline Flexor carpi ulnaris & $\begin{array}{l}\text { Caudal epicondyle of } \\
\text { the humerus and ulna }\end{array}$ & Ulnare & $\begin{array}{l}\text { Muscle with two origins. It is } \\
\text { large, thick and fusiform. } \\
\text { Medial to the pronator } \\
\text { quadratus and deep to the flexor } \\
\text { digitorum longus }\end{array}$ \\
\hline Pronator quadratus & $\begin{array}{l}\text { From a broad } \\
\text { attachment to the ulna }\end{array}$ & $\begin{array}{l}\text { Distal lenght of the } \\
\text { radius }\end{array}$ & $\begin{array}{l}\text { A broad muscle deeply located } \\
\text { in the antebrachium } \\
\text { Most superficial flexor of the }\end{array}$ \\
\hline Trasversus palmaris & Distal radius & Metacarpal V & $\begin{array}{l}\text { manus. Strap-like, thin and } \\
\text { transversal fibered, attached to } \\
\text { a long tendon }\end{array}$ \\
\hline Flexor digiti quinti & $\begin{array}{l}\text { Lateral margin of the } \\
\text { radiale }\end{array}$ & Distal phalanx V & $\begin{array}{l}\text { Small, thin and triangular } \\
\text { superficial muscle in the manus }\end{array}$ \\
\hline $\begin{array}{l}\text { Flexor digitorum brevis } \\
\text { superficialis }\end{array}$ & $\begin{array}{l}\text { Proximal metacarpal } \\
\text { bones (I - IV digits) }\end{array}$ & $\begin{array}{l}\text { Phalanx II (I -IV } \\
\text { digits) }\end{array}$ & $\begin{array}{l}\text { Complex of four small, } \\
\text { fusiform, and deep muscles in } \\
\text { the palmar surface. }\end{array}$ \\
\hline $\begin{array}{c}\text { Extensor digitorum } \\
\text { superficialis }\end{array}$ & $\begin{array}{l}\text { Distal carpal and } \\
\text { proximal metacarpal }\end{array}$ & $\begin{array}{l}\text { Distal phalanx (I-V } \\
\text { digits) }\end{array}$ & $\begin{array}{l}\text { Complex of various muscle } \\
\text { heads. Small, elongated and } \\
\text { superficial in the dorsal manus. }\end{array}$ \\
\hline
\end{tabular}


According to Abdala and Diogo, ${ }^{(22)}$ the infraespinatus and supraespinatus muscles in mammals derive from supracoracoideus, although it occupies a ventral and not dorsal portion in the current tetrapoda ${ }^{(21)}$, except for chameleons, where the dorsal position supracoraoideus would be an autopomorphical condition. ${ }^{(19)}$ Crocodilians have no infraespinatus and supraespinatus muscles.

The deltoideus appeared as two distinct muscles. The deltoideus scapularis is usually connected to the scapula, but it can occasionally be present in the humerus. ${ }^{(25)}$ It is present in crocodilians, birds, testudines and lepdosauria. ${ }^{(22,25,27)}$ Diogo et al. ${ }^{(21)}$ claimed that it is present in reptiles, mammals and amphibians basically with the same topography and function that, according to Meers ${ }^{(24)}$ and Romão et al., ${ }^{(23)}$ performs the extension of the humerus and assists in stability of the joint. In C. crocodilus crocodilus and the reported crocodilians, it is a robust muscle, with extensive areas of cross sections topographically deep to the trapezius of the dorsal region (Fig. 1). It is inserted into the deltopectoral crest of the humerus by a strong tendon.

The teres major muscle is present in all the reported crocodilians corroborating Dilkes ${ }^{(25)}$ to further confirm its presence in testudines and many lizards (except Iguana). In A. mississippinensis ${ }^{(24)}$ and C. latirostris, ${ }^{(23)}$ this muscle has interdigitated fibers with the latissimus dorsi. Its insertion occurs by a single and fused tendon between these. Such union of fibers was not observed in C. crocodilus crocodilus, being both distinct. The extensive cross-sectional area suggests that this muscle provides great mechanical support for the stability of the forelimb. Howell ${ }^{(28)}$ infered that the greatest round in mammals is not homologous to the reptiles, Diogo et al., ${ }^{21}$ however, defended this homology. Based on the descriptions by Meers, ${ }^{(24)}$ this homology is plausible because of the topography and innervation of that muscle.

From a simple survey, it is possible to observe the large degree of variation in the number of divisions present in the crocodilian triceps towards other reptile and tetrapoda. The triceps is present in lepdosauria with four heads, ${ }^{(25,27)}$ with two heads in testudines, ${ }^{(27)}$ although only one head is reported in Dermochelys, and three heads in poultry. ${ }^{(25)}$

Holmes $^{(27)}$ described four heads for this muscle in crocodilians and defended that this is a plesiomorphic condition for reptiles, while for Diogo et al., ${ }^{(21)}$ this would be a pleisiomorphy for all tetrapods. Meers, ${ }^{(24)}$ however, reported five heads, corroborating Dilkes, ${ }^{(25)}$ as well as our description for $C$. crocodilus crocodilus (Fig. 1). Romão et al. ${ }^{(23)}$ described five heads and an additional one, acessorius to the longus medialis head, with the proximal origin in the aponeurosis that covers the longus medialis head. This characteristic has been described by Meers ${ }^{(24)}$ in an exemplar of $A$. mississippiensis and $C$. actus.

Romão et al. ${ }^{(23)}$ described in C. latirostris a head of triceps originated from a double tendon forming a tendinous arch linking the scapula and the coracoid, and nnamed it "tríceps longo medial" (triceps longus medialis). However, the same description for the other crocodilians, including C. crocodilus crocodilus, is named triceps longus caudalis. ${ }^{(22,24)}$ Such tendinous arch is present in all crocodilians, although with different topography. The existence of this structure in the triceps muscle highlights the need for additional studies aiming to explain the phylogeny and homology of the muscles in Archosauria. ${ }^{(24)}$

All descriptions of the biceps brachii to crocodilians, also in C. crocodilus crocodilus, have reported the existence of a long and slender fusiform head, originated in the cranial margin of the coracoid and a robust insertion into the radius tuberosity ${ }^{(22-24)}$ (Figs. 1, 2).

The biceps brachii in testudines has two heads. Meers ${ }^{(24)}$ and Romão et al. ${ }^{(23)}$ reported the existence of a second belly inconspicuous, inconstant and originated in the capsule of the shoulder joint in $C$.

latirostris and A. mississippiensis. In C. crocodilus crocodilus, this characteristic was not observed, and the biceps brachii had a single fusiform head as described by Diogo et al. ${ }^{(21)}$

Some species showed a shift of the biceps brachii origin ventromedially that provides mechanical advantage by promoting strong flexion, although no explicit description depicted such a feature in the reported species. ${ }^{(24)}$

The forearm muscles can be divided into three groups: ventral (flexor and pronator), dorsal (extensor and supinator) and hand muscles. These are topographically organized in layers flexor/extensor ulnaris, flexor/extensor radialis and flexor/extensor digitorum. ${ }^{(21)}$ Observing the reported topography for A. mississippiensis, $C$. latirostris and C. crocodilus crocodilus this relationship can be easily noticed. 


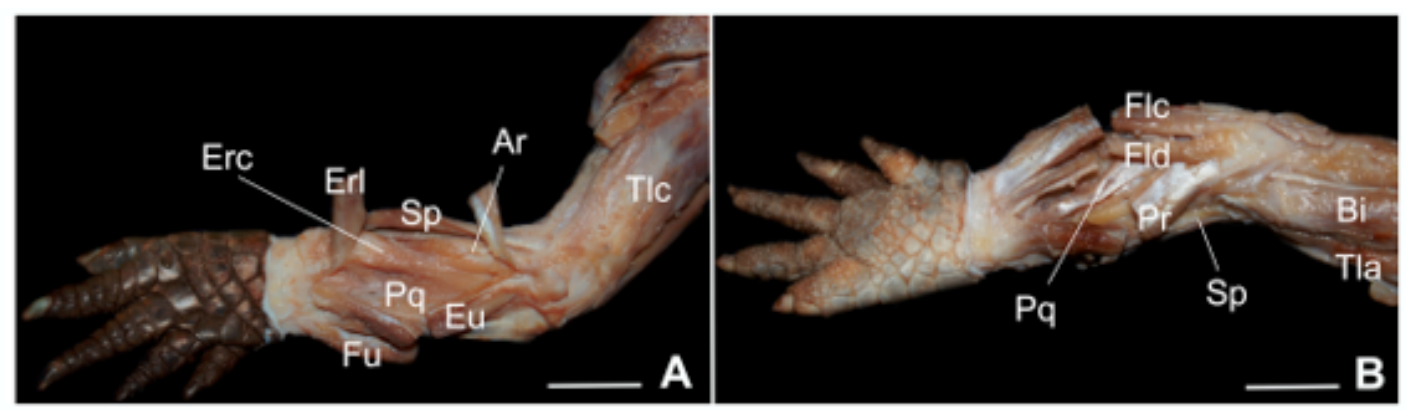

Figure 2: Antebrachium of the Caiman crocodilus crocodilus, lateral view (A). Tlc, triceps longus caudalis; Ar, abductor radialis; $\mathrm{Sp}$, supinator; Eu, extensor carpi ulnaris; $\mathrm{Pq}$, pronator quadratus; $\mathrm{Fu}$, flexor carpi ulnaris; Erc, extensor carpi radialis brevis; Erl, extensor carpi radialis longus. Medial view (B). Flc, flexor ulnaris; Fld, flexor digitorum longus; $\mathrm{Pr}$, pronator teres; $\mathrm{Bi}$, biceps brachii. ScaleBar $=3 \mathrm{~cm}$.

Some variations between the flexor and extensor muscles in the forearm can be punctuated in crocodilians. According to Diogo et al., ${ }^{(21)}$ there is some confusion in the identification of the flexor carpi and the pronator teres in reptiles. According to the authors, both heads of the flexor carpi and pronator teres correspond topographically with these in mammals. Some groups of reptiles, such as testudines and lepdosauria, show an accessory pronator, lost by crocodilians. ${ }^{(22,24,29)}$ We classified the forearm muscle present in the flexor compartment of $C$. crocodilus crocodilus as flexor digitorum longus (and respective heads), as reported by Meers ${ }^{(24)}$ for $A$. mississippiensis and Romão et al. ${ }^{(23)}$ for C. latirostris. Our findings corroborated Meers, ${ }^{(24)}$ who described a humeral head originated from the caudal epicondyle, pars ulnaris with the source on the surface of the ulna and another pars carpalis. To C. latirostris only the pars humeralis and pars ulnaris were described. ${ }^{(24)}$ All divisions form a common tendon on the palmar surface. Starting from a branch point, it occurs in three separate tendons that go to the digits I-III, as in C. crocodilus crocodilus. Regarding C. latirostris, ${ }^{(23)}$ this last branch of the tendons to the digits was not reported (Figs. 1, 2).

As for the extensor muscles, the existence of two radialis carpalis extensors muscles is not a consensus. Howell ${ }^{(30)}$, Meers, ${ }^{(24)}$ and Romão et al. ${ }^{(23)}$ described one short and another long muscle in crocodilians, but some authors defended that the reptile present a single muscle. Diogo et al. ${ }^{(21)}$ described a single extensor carpi radialis (brevis), but with three heads (superficialis, profundus and supinator) as in testudines, lepdosauria and amphibians, ${ }^{(25,26,31)}$ except for some variations. Meers ${ }^{(24)}$ reported that crocodilians present two discrete heads for the extensor carpi radialis brevis muscle (pars radialis and pars ulnaris), both described in $C$. latirostris, ${ }^{(23)}$ and $C$. crocodilus crocodilus; however, with a slight variation in the insertion points.

Meers ${ }^{(24)}$ and Romão et al. ${ }^{(23)}$ described the extensor ulnaris that, according to Abdala and Diego, ${ }^{(22)}$ corresponds to the extensor ulnaris of the carpi and the antebrachium described by Holmes ${ }^{(27)}$ and Dilkes. ${ }^{(24)}$ This extensor ulnaris has the same morphology and topography for $C$ crocodilus crocodilus, it originated from the cranial epicondyle of the humerus and inserted in the caudal surface of the ulna (Figs. 1, 2). According to Haines, ${ }^{(32)}$ it is a muscle with a wide variation among the vertebrates, which shows different actions. In crocodilians it acts as a postural stabilizer.

Several extensor digitorum muscles were reported by Meers ${ }^{(24)}$ and Diogo et al. ${ }^{(21)}$ There are five superficial, six deep, two extenders for the metacarpal and a superficial extensor for the digits I and II, ${ }^{(24)}$ probably corresponding to extensor digitorum, extensor longus digit 1 and abductor pollicis longus described by Diogo et al. ${ }^{(21)}$ From these ones, the extensor digitorum superficialis had been described for $C$. crocodilus crocodilus with similar morphology, presenting five bellies with insertion through individual tendons at the distal phalanx of each digit (I-V).

The flexor digitorum superficialis brevis in C. crocodilus crocodilus corresponds to four small, elongated and peniform bellies originated in the retinaculum flexor level and insertion in the phalanx II (Fig. 3). The digit V has a distinct flexor muscle, as observed by Meers. ${ }^{(24)}$ He reports the existence 
of an additional muscle, flexor digitorum intermedius digiti $\mathrm{V}$ in $A$. mississippiensis, and according to him, it commonly occurrs at the digiti IV and V, although it was not observed in $C$. crocodilus crocodilus or other crocodilian.

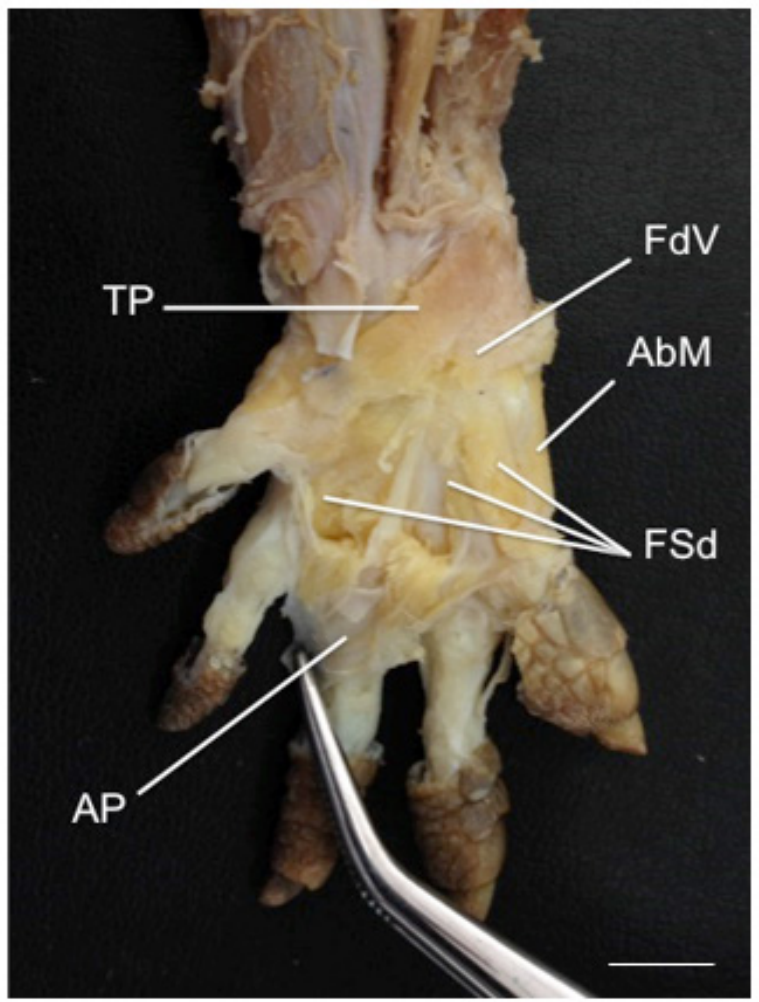

Figure 3: Manus of the Caiman crocodilus crocodilus, palmar view. $\mathrm{Tp}$, trasversus palmaris; FdV, flexor digiti quinti; Abm, abductor metacarpi I; FSd, flexor digitorum superficialis brevis; AP, palmar aponeurosis. ScaleBar $=3 \mathrm{~cm}$.

\section{Conclusion}

Although there is a reduction or loss of some muscle structures from the comparison between crocodilians and other reptiles, it is possible to determine the presence of various muscles, including the same morphological characteristics in larger groups of reptiles including birds, suggesting the existence of a similar pattern in this group. The proximal segments have some variation, but large differences are reported in the distal member. These changes derive from this segment specialization in different groups and species with the development of specific skills, especially related to the locomotion pattern.

\section{Acknowledgments}

The authors thank to National Center for Research and Conservation of Reptiles and Amphibians (RAN), of the Chico Mendes Institute for Biodiversity Conservation (ICMBio).

\section{References}

1. Rieppel O, Reisz RR. The origin and early evolution of Turtles. Annu. Rev. Ecol. Syst., 1999; 30: 1-22. 
2. Schoch RR. Early larval ontogeny of the Permo-Carboniferous temnospongyl Sclerocephalus. Paleontol., 2003; 46: 1055-1072.

3. Colbert EH. Relationships of the saurischian dinosaurs. Am. Mus. Nov., 1964; 2181: 1-24.

4. Brinkman D. The hind limb step cycle of Caiman sclerops and the mechanics of the crocodile tarsus and metatarsus. Can. J. Zool. 1980; 58: 2187-2200.

5. Reilly SM, Elias JA. Locomotion in Alligator mississippiensis: Kinematic effects of speed and posture and their relevance to the sprawling-to-erect paradigm. J. Exp. Biol. 1998; 201: 2559-2574.

6. Reilly SM, Blob RW. Motor control of locomotor hindlimb posture in the American alligator (Alligator mississippiensis). J. Exp. Biol., 2003; 206: 4327-4340.

7. Naish D. Fossils explained: Crocodilians. Geol .Today, 2001; 17: 71-77.

8. Brochu CA. Phylogenetic approaches toward crocodylian history. Anuu. Rev. Earth P1. Sc. 2003; 31: 357397.

9. Magnusson WE, Sanaiotti TM. Growth of Caiman crocodilus crocodilus in central Amazônia, Brazil. Copeia, 1995; 2: 498-501.

10. Campos Z, Coutinho M, Magnusson WE. Terrestrial activity of caiman in the Pantanal, Brazil. Copeia, 2003; 3: 628-634.

11. Da Silveira R, Campos Z, Thorbjarnarson JB, Magnusson WE. Growth rates of black caiman (Melanosuchus niger) and spectacled caiman (Caiman crocodilus) in two different Amazonian flooded habitats. AmphibiaReptilia, 2013; 34: 437-449.

12. Borges-Nojosa DM, Arzabe C. Diversidade de anfíbios e répteis em áreas prioritárias para a conservação da Caatinga. In: Araújo FS, Rodal MJN, Barbosa MRV. eds. Análise das variações da biodiversidade do bioma Caatinga. 1st ed. Brasília: Ministério do Meio Ambiente, 2005. 226p.

13. Campos Z, Mourão G, Coutinho M, Magnusson W. E.Growth of Caiman crocodilus yacare in the Brazilian Pantanal. PloS ONE, 2014; 9: 1-5.

14. Gatesy SM. Hind limb scaling in birds and other theropods: implications for terrestrial locomotion. J. Morphol., 1991; 209: 83-96.

15. Erickson GM, Gignac PM, Steppan SJ, Lappin AK, Vliet KA, Brueggen JD, Inouye BD, Kledzik D, Webb GJW. Insights into the ecology and evolutionary success of crocodilians reveals through bite-force and toothpressure experimentation. PLoS ONE, 2012; 7, 1-12.

16. Chamero B, Buscalioni AD, Marugán-Lobón J. Pectoral girdle and forelimb variation in extant Crocodylia: the coracoid-humerus pair as an evolutionay module. Biol. J. Linn. Soc., 2013; 108: 600-618.

17. Hutchinson JR, Gatesy SM. Adductors, abductors, and the evolution of archosaur locomotion. Paleobiol., 2000; 26: 734-751.

18. Hutchinson JR. Biomechanical modeling and sensitivity analysis of bipedal running ability. Extinct taxa, J. Morphol., 2004; 262: 441-460.

19. Romer AS. The development of tetrapod limb musculature - the shoulder region of Lacerta. J. Morphol., 1944; 74: 1-41.

20. Russell AP, Bauer, AM. The appendicular locomotor apparatus of Sphenodon and normal-limbed squamates. In: Gans C, Gaunt AS, Adler K. Biology of Reptilia. 2 st ed. New York: Society for the Study of Amphibians and Reptilian; 2008. 295p.

21. Diogo R, Abdala V. Aziz MA, Lonergan N, Wood BA. From fish to modern humans - comparative anatomy, 
homologies and evolution of the pectoral and forelimb musculature. J. Anat., 2009; 214: 694-716.

22. Abdala V, Diogo R. Comparative anatomy, homologies and evolution of the pectoral and forelimb musculature of tetrapods with special attention to extant limbed amphibians and reptiles. J.Anat., 2010; 217: 536-573.

23. Romão MF, Santos ALQ, Lima FC. Anatomia descritiva aplicada a cinesiologia e biomecânica básica dos músculos da cintura peitoral, estilopódio e zeugopódio do jacaré do papo amarelo. Cienc. Rural, 2013; 43: 631-638.

24. Meers MB. Crocodylian forelimb musculature and its relevance to Archosauria. Anat. Rec., 2003; 274A: 891-916.

25. Dilkes DW. Appendicular myology of the hadrosaurian dinosaur Maiasaura peeblesorum from the Late Cretaceous (Campanian) of Montana. T. Roy. Soc. Edin-Earth, 2000; 90: 87-125.

26. Hudson GE, Schreiweis DO, Wang SYC. A numerical study of the wing and leg muscles of Tinamous (Tinamidae). Northwest Sci., 1972; 46: 207-255.

27. Holmes R. The osteology and musculature of the pectoral limb of small captorhinids. J. Morphol., 1977; 152: $101-140$

28. Howell AB. Morphogenesis of the shoulder architecture, Part IV - Therian Mammalia. Q. Rev. Biol., 1937; 12: $440-463$.

29. Straus WL. The homologies of the forearm flexors: urodeles, lizards, mammals. Am. J. Anat., 1942; 70 : 281-316.

30. Howell AB. Phylogeny of the distal musculature of the pectoral appendage. J. Morphol., 1936; 60: $287-$ 315.

31. Abdala V, Manzano AS, Herrel A. The distal forelimb musculature in aquatic and terrestrial turtles: phylogeny or environmental constraints? J.Anat., 2008; 213: 159-172.

32. Haines RW. The flexor muscles of the forearm and hand in lizards and mammals. J. Anat., 1950; 84: 13-29. 